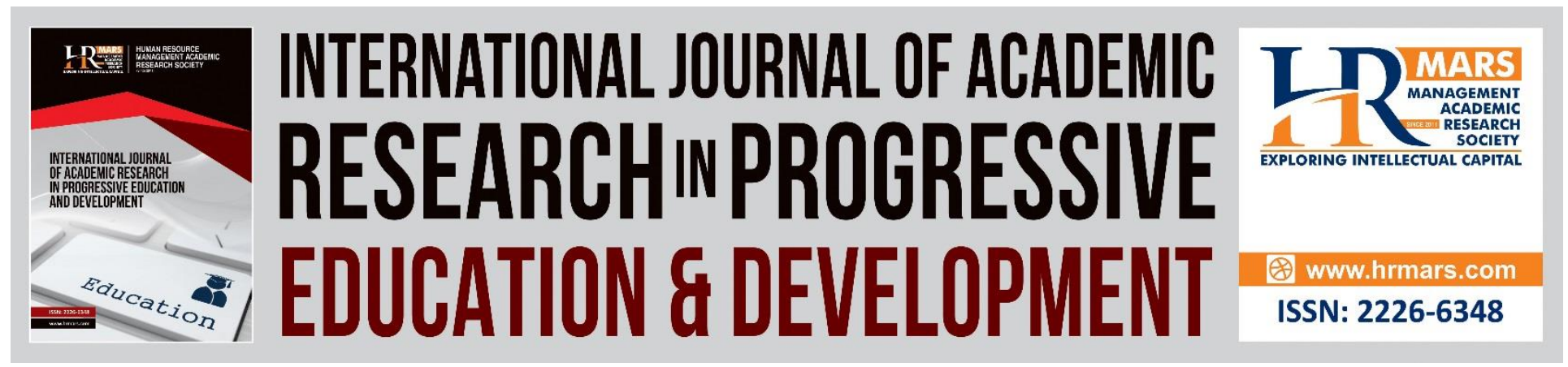

\title{
The Impact of WhatsApp as an Instructional Tool for Online Distance Teaching and Learning (ODL)
}

Syarifah Adilah Mohamed Yusoff, Rozita Kadar, Wan Anisha Wan Mohamad, Azlina Mydin, Mohd Hanapiah Abdullah

To Link this Article: http://dx.doi.org/10.6007/IJARPED/v10-i2/10141 DOI:10.6007/IJARPED/v10-i2/10141

Received: 06 April 2021, Revised: 29 April 2021, Accepted: 18 May 2021

Published Online: 10 June 2021

In-Text Citation: (Yusoff et al., 2021)

To Cite this Article: Yusoff, S. A. M., Kadar, R., Mohamad, W. A. W., Mydin, A., \& Abdullah, M. H. (2021). The Impact of WhatsApp as an Instructional Tool for Online Distance Teaching and Learning (ODL). International Journal of Academic Research in Progressive Education and Development, 10(2), 585-595.

Copyright: (C) 2021 The Author(s)

Published by Human Resource Management Academic Research Society (www.hrmars.com)

This article is published under the Creative Commons Attribution (CC BY 4.0) license. Anyone may reproduce, distribute, translate and create derivative works of this article (for both commercial and non-commercial purposes), subject to full attribution to the original publication and authors. The full terms of this license may be seen at: http://creativecommons.org/licences/by/4.0/legalcode

Vol. 10(2) 2021, Pg. 585 - 595

Full Terms \& Conditions of access and use can be found at http://hrmars.com/index.php/pages/detail/publication-ethics 


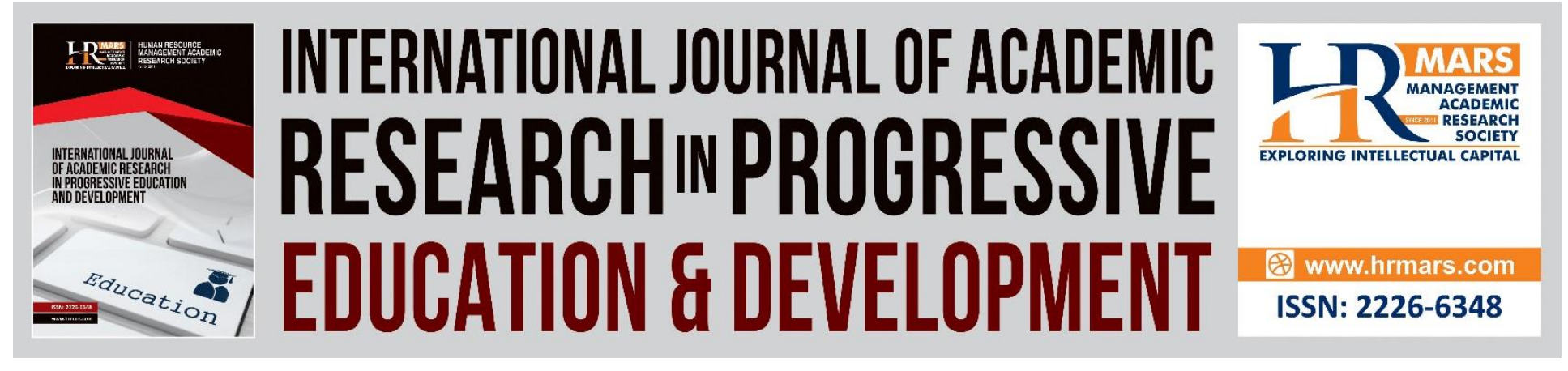

\title{
The Impact of WhatsApp as an Instructional Tool for Online Distance Teaching and Learning (ODL)
}

\author{
Syarifah Adilah Mohamed Yusoff ${ }^{1}$, Rozita Kadar ${ }^{1}$, Wan Anisha \\ Wan Mohamad ${ }^{1}$, Azlina Mydin ${ }^{1}$, Mohd Hanapiah Abdullah ${ }^{2}$ \\ ${ }^{1}$ Department of Computer and Mathematical Sciences, ${ }^{2}$ Faculty of Electrical Engineering, \\ Universiti Teknologi MARA Cawangan Pulau Pinang, Malaysia
}

\begin{abstract}
Pandemic issue of COVID19 has poorly affected the whole world activities that includes face-toface human communications. Every level of educations sector is required to suddenly change into online and distance learning mode. Focusing to tertiary education level, this research was conducted to investigate the usefulness and effectiveness of WhatsApp as the most popular social media medium in community as teaching and learning medium for course computer programming language of $\mathrm{C}++$. In order to measure the usefulness, WhatsApp features are evaluated to accomplish teaching and learning students' perception. Next, students' attitude towards learning process were evaluated as learning behavior. The result showed the WhatsApp was convenient for teaching and learning online when all features are fully utilized and improve positive attitudes toward self-learning.

Keywords: Online Distance Learning, E-learning tool, WhatsApp, Online Chatting, Teaching and Learning

Introduction to Teaching and Learning for Higher Education Students

Education is the most powerful weapon which can improve life and quality of thinking of a nation. Hence, there always being government continuous targets to improve strategically the curriculums, facilities and anything that concern education from early childhood until tertiary levels. Besides, IR4.0 is inevitable, it is happened when artificial intelligence, cloud computing, Internet of Things (IOT) and Big Data Analytic are blended together in industry and enables the development of automated, intelligent and connected products and services. Hence, demands workers that are multi-skills and long-life learners.

High-level education is almost the last stage of education that train students to be prepared with any demand from the industries. They have to be competence, long-life learner and multiple intelligence. According to Diwan (2017) learning for high- level education should consist of 5l's
\end{abstract}


which are imbibing, iterating, interpreting, interest and innovating. These $5 \mathrm{l}$ 's are aimed in order to produce students that equip with problem solving and decisions making skills.

Across disciplines, the way education is conducted and the content is delivered together with the syllabus have to amend in order to support IR4.0 that embrace complete digital and data literacy. The convergence of human and machine in IR4.0 will mean that disciplinary distance between science and technology, humanities and social sciences decrease. Therefore, the highly creative graduates with ability to think critically in innovative ways are required to support the emergence and working environment with not only human, but also robots. The cognitive skills, application, analysis, evaluating and creating are required skills to deal with complex task since the specialist jobs remains though, meanwhile the entry-level professionals replaced with robots.

Student's independent learning is a part of long-life learning skill where, they are able to use their own experience blend with internal processes such as reflection, environmental scanning and interaction with others to engage with meaningful learning activities driven by their interest. Interaction with peers in accomplish their education goals through co-creation of communities of learning and the use of virtual learning promote immerse learning in accomplishing the learning goals. Therefore, the creation of MOOC platform, blended learning and E-learning initiate the students to engage with technology for independent and long-life learning.

The pandemic issues instantly push universities to change from the traditional ways of learning which is face-to-face to online distance learning (ODL). The learning concept itself suddenly change from too much rely on lecturer to almost self-learning and isolated at the student's hometown.

Online distance learning, e-learning, blended learning has the same goal which is to have virtual teaching and learning session either students are in-campus or off-campus. The issues of this virtual vs traditional face-to-face teaching and learning methods are varied from community communication behaviour, supported technology and infrastructure, nature of the courses, and university policy. This study has investigated the use of WhatsApp as online instant communication applications for online distance learning when the pandemic movement control order (MCO) was implemented in Malaysia.

\section{Online Instant Communication for Teaching and Learning}

The most available and undeniable application for online and instant communication is WhatsApp (WA). In Malaysian community, almost 97 percent internet user population known and used WhatsApp as most frequently used and convenient application for communication among colleagues (Telenor Research, 2016). Automatically it is known as the top instant messaging application in the country even the growth is showing no sign of slowing down.

Instead of WA there are others several popular instant communication applications used throughout the world such as Facebook messenger, Telegram, WeChat, Viber and Line. Narrowing the scope of user as students, several demanding features for instant communication are free, seamless, light-weight, fast, cross-platform and devices. These features are very important when they are communicating among themselves in a small group to texting, voice messaging, sharing images and various format of files. Hence, applications with the mentioned 
features are suitable innovatively to replace teaching in traditional classroom especially when covering geographical area that has limited internet connection.

Laschewski (2011) has defined principal of innovation in online learning are classified as learner orientation, interactivity/community development, micro-learning, interoperability, efficiency, institutionalization, quality management and evaluation. The WA covers innovation not only as learner orientation but also community development and efficiency if we consider the features of online instant communication as mentioned above.

Several studies have stated the effectiveness of learning through WA application in several area such as nursing, management and English ESL class. Amry, A. B. (2014) has discussed the used of WA as learning medium that effect the achievement and attitude of female students on university level. A survey has been done by comparing group control that learn chapter 6 of Education Media course, meanwhile second group of students learn using WA. The result showed the effective improvement towards final test, when learning using WA compared to face to face. Furthermore, the usage of WA among students were claimed improving community level interaction and social presence among students. The bonds that happen among students and instructor leads to casual learning style and trigger two-way communication along learning process.

Similar study was done by Hassan and Ahmed (2018) from sample of undergraduate students for English Language class in University King Khalid, Saudi Arabia by engaging sample of 60 male students with additional support through WA group. The investigations have focused on level of motivation, content knowledge and grades of students. Traditional class of learning that studying the theoretical structures of English language was difficult due to poor background knowledge in English from secondary level of education, lack of motivation to study and large classes. The problems are still hanging even the instructors offer 15 hours of consultation in their office per week when few students turned up. The research has been done by providing additional support for sample of 60 male students using WA group as from 8 pm to 10pm every night except Friday. The discussions are focusing on chatting, texting, calling and sharing problems, documents and video clips. The result of final grade provided significant improvement where there is no failure among experimental students which have been assisted using WA for the course. Further, students' self-esteem towards learning English language are increase due to regular interaction among fellow members as well as the instructor.

Mistar \& Embi (2016); Shariffuddin, Shaaidi \& Hashim (2017) both studies implemented WA as instructional tool outside classroom for learning ESL for Malaysian higher education students. Both studies were focusing in identifying the significant of learning English language via WA medium and students' perception in using the application. The results reported that WA application has proven to be the best social application for learning medium not only because of the features but it has been widely used in Malaysian community specialised to younger generation.

Pratama \& Kartikawati (2017) have studied the usage of WA application as learning instruction for Elementary Electronic course. Sample of 34 students of Electrical Engineering Education Study were split into two groups of experiment and control evenly. The WA application was used to sharing the video of experimental activities done in laboratories related to the course. The results showed the proposed method has given positive impact to the learning outcome such as 
simulating learning innovation as active learner, effective communication among colleague and independent learners. The results have also been supported by other descriptive study done by Rahaded, Puspitasari, \& Hidayati (2020). The research focusing towards the use of WA to facilitate communication of undergraduate students at Ahmad Dahlan University Indonesia for education purposes. The data were collected using interview, observation and documentation. The learning process considered by this study were students' sharing knowledge, student preparation for class, attention, student participation in class, student learning and desires to take additional classes or in subject matter. The results have indicated that this innovative educational technology-based mobile learning helps students to create learning community, to easy construct knowledge and to share it with other members.

\section{Methodology}

This study adopted descriptive survey method by designing questionnaire to the Civil Engineering students from part 3, 4 and 5. They are novice programmer and learn computer programming language of $\mathrm{C}++$ for first the time. The questionnaires for instructional, learning and communications were adapted both from Aina and Ogundele (2014) and Alfaki and Alfarthy (2014). Meanwhile for attitude questionnaires were adapted from Amry, A. B. (2014). The adaptations were done to fulfil the following objectives by considering the features of instant chatting application of WA in learning computer programming language of $\mathrm{C}++$ :

I. How effectives WA features helps in engaging students throughout teaching and learning session?

II. What is students' attitude towards the use of WA in learning programming language?

III. What are the benefits and drawbacks of WA in teaching and learning programming language?

Further, since the survey were done at the beginning of Malaysian Movement Control Order (MCO) 2020. All lecturers were automatically conducted their classes in Online Distance Learning (ODL) mode, which no classes for face-to-face. Prior to this semester, students and lecturer of this course has no experience in doing online classes except small discussion through group WA of their own group course. Due to the MCO restriction, several features considered as limitations were as follows:

1. Lecturers and students used their own personal internet connections to do online ODL.

2. Computer equipment was also restricted to personal devices belongs to Lecturers and students, such as laptop, digital pen, webcam, head/hear phone.

The samples were collected from 61 students of Civil Engineering students from part3, 4 and 5 for the same lecturer in order to have consistent answers toward teaching and learning. Anyhow, these students were split into three small groups randomly to make sure the ODL were done efficiently and lecturer able to focus each of them properly. The analysis was made for teaching and learning begun from chapter 3 until 6 which were selection, repetition, function and array respectively. Class sessions were 2 hours per meeting and happen two times per week. In the 
Vol. 10, No. 2, 2021, E-ISSN: 2226-6348 @ 2021 HRMARS

beginning of the class, lecturer shared video lectures that covered part of lesson they should learn for that particular week. The videos were made by the lecturer in MP4 format and constructed using Microsoft Power Point video recording. Students required to spent 30 to 45 minutes to watch the video and have their own self-learning time to taking notes. The rest of 1 hour and 15 minutes were left for WA learning process. The process of teaching and learning has been repeated until chapter 6 which was array's chapter.

The questionnaire responses by the respondents were calculated using descriptive analysis of which frequencies and percentages were tabulated in order to better comprehend the result.

\section{Finding and Discussions}

Prior the study, the lecturer consistently used WA as additional instructional tools for outside class discussions and to make sure students has no hesitation in sharing problems. Besides, WA was used to share files related to the courses such as pdf and images files. Anyhow, beginning of early semester of March 2020, all higher education institutions in Malaysia have fully operated online using any suitable technology that suited with the students both in capabilities to connect with internet and usability of the software among students. Students also experienced of using other applications as tool for online teaching and learning such as Google Meet, Microsoft Team, MOOC and many more for other courses. The WA was chosen for this course to accommodate with limitation bandwidth and internet connections in certain area of students' home town. Some of the students have difficulty to access internet for seamless video conference connection, engaged the whole day for lectures session and further self-revision purposes.

Literatures and feedback from previous studies have convinced the use of WA for teaching and learning of this course. Instead of WA were use as additional instructional medium outside class but, in this study, WA was used as teaching and learning replacing face-to-face lecture. Before the ODL session begins, students have been motivated about self-learner attitudes towards ODL implementation and no more lecturer's dominant in class lecture. Meanwhile, lecturer also develop video lecture that consist of text, verbal explanation and annotation to help and make sure students feel such as in class discussion. Further, in the end of semester a survey was done and the descriptive analysis evaluated to prove that text and voice messages, video, images of WA features are utilized as an instructional tool to teach programming language of $\mathrm{C}++$.

Table 1 has described the usefulness of WA features as instructional tools. Firstly, it is obvious from the result students were satisfied with the content of the video prepared by lecturer and shared via WA application at the beginning of each class sessions (Q1). Instead of the videos are interactive (Q2), the students clearly understand the fundamental idea of each chapter when rated as $95 \%$ as clearly understand the lesson (Q3). Convincingly, more than $50 \%$ of the students agree the videos suitable and better than online sources as main reference for the lessons (Q4). Figure 1 showed all video lecture created by their own lecturer and shared throughout the semester. Meanwhile Figure 2(a) showed an example of sharing video session in one of the student's group WA. 


\section{INTERNATIONAL JOURNAL OF ACADEMIC RESEARCH IN PROGRESSIVE EDUCATION AND}

DEVELOPMENT

Vol. 10, No. 2, 2021, E-ISSN: 2226-6348 @ 2021 HRMARS

It is fascinating that WA is capable in attracting students to engage and participate with chatting and discussion session after watching the video lecture for 30 to 40 minutes. The percentage of 96.7 were agreed in participating with the discussion is a success in teaching compared with faceto-face teaching when students almost lost in between teaching due to boredom (Q5). Hence, there is no doubt when 93.4 percent agreed that doing exercise and discussion help them to improve the lesson learnt (Q6). Figure 2(b) showed texting and image sharing happened in WA. The two-way interactions that happen between students and lecturer promotes confidents among them and obviously responsive exercises were sufficient for them to understand the lesson (Q7). Face-to-face was preferable for students in focusing lesson compared to WA (Q8), even there is no significant differences among agree and disagree which is 4.7 percent. Anyhow, this point of view maybe needs further research to clarify the reason since the responses strongly agree they were not at all shy when asking questions to lecturer via WA and admit it helps them to understand better compared to face-to-face(Q9).

Another features of WA that has intrigued and helped to improve teaching and learning mood via WA was voice message of the lecturer (Q10). Mixing of text and voice message has provided better attention and understanding when more than 90 percent respondents agree the use of voice message in further explained for the lesson. Figure 2(c) shared print screen of students' reaction for voice message from lecturer that lighted up students' mood. Further, confidence is achieved when students understand the lesson hence leads for self-learning activities (Q11). Figure 2(d) showed how they helping each other to re-correct their coding exercise. This fascinating attitude won't happen if they have no confident and relations among members of group.
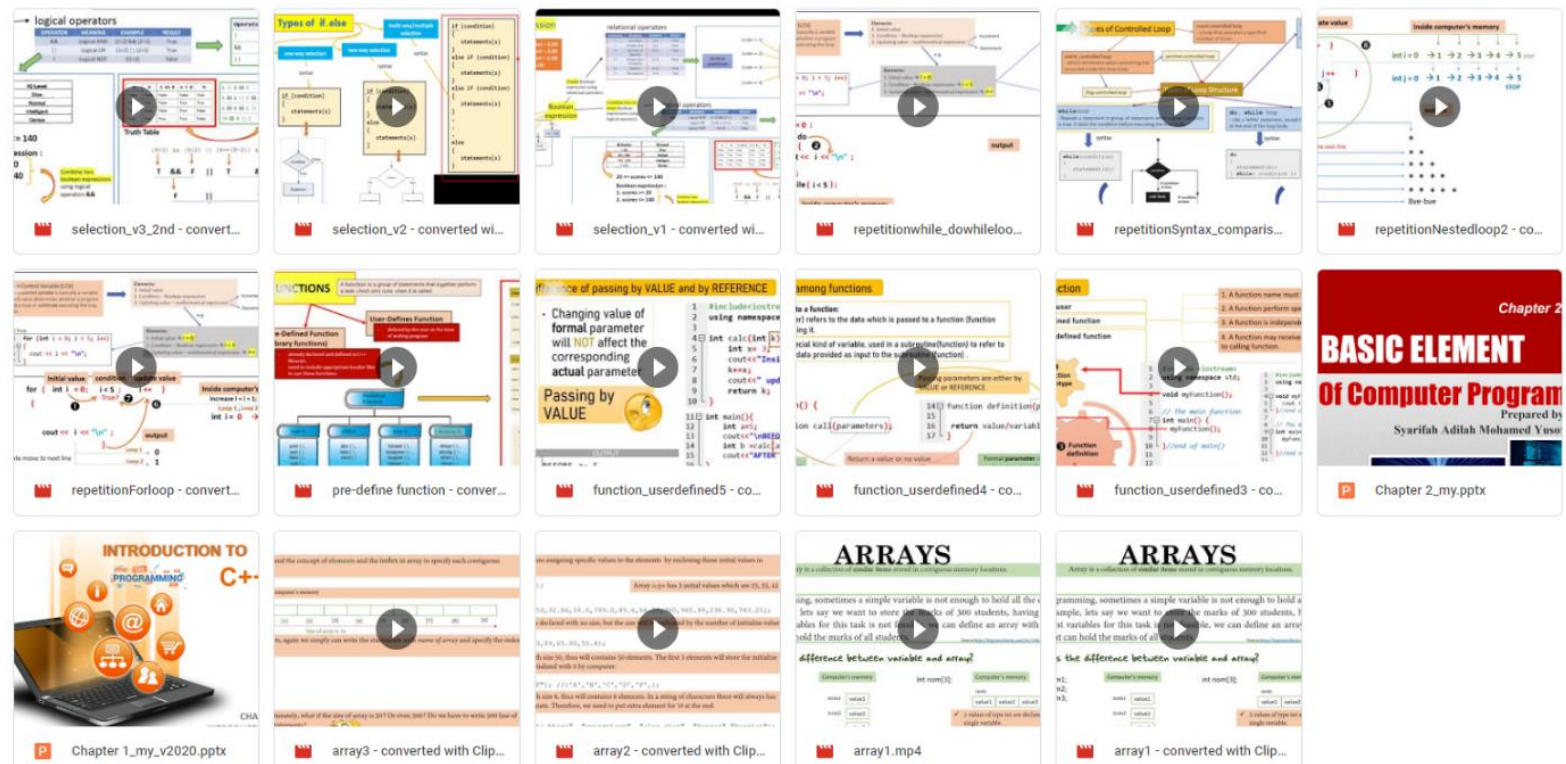

ARRAYS

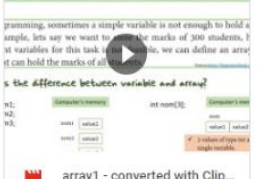

Figure 1. Video lecture prepared by the lecturer for learning $\mathrm{C}++$ programming 
INTERNATIONAL JOURNAL OF ACADEMIC RESEARCH IN PROGRESSIVE EDUCATION AND DEVELOPMENT

Vol. 10, No. 2, 2021, E-ISSN: 2226-6348 @ 2021 HRMARS

Table 1. Students perception using WA as teaching and learning

\begin{tabular}{|c|c|c|c|c|c|}
\hline \multirow{2}{*}{\multicolumn{2}{|c|}{ Questions }} & \multicolumn{2}{|c|}{ Agree } & \multicolumn{2}{|c|}{ Disagree } \\
\hline & & \multirow{2}{*}{$\begin{array}{l}\% \\
100\end{array}$} & \multirow{2}{*}{$\begin{array}{ll}f \\
61\end{array}$} & \multirow{2}{*}{$\begin{array}{ll}\% \\
0\end{array}$} & \multirow{2}{*}{$\begin{array}{lr} & \mathbf{f} \\
0 & \end{array}$} \\
\hline Q1 & $\begin{array}{l}\text { Do you satisfy with the content of video lecture } \\
\text { shared by your lecturer? }\end{array}$ & & & & \\
\hline Q2 & $\begin{array}{l}\text { Do you think the video lectures were interactive } \\
\text { (engaging multimedia elements)? }\end{array}$ & 93.4 & 57 & 6.6 & 4 \\
\hline Q3 & $\begin{array}{l}\text { Does the video lectures help you to understand the } \\
\text { lesson clearly? }\end{array}$ & 95 & 58 & 5 & 3 \\
\hline Q4 & $\begin{array}{l}\text { Do you prefer to change from video lecture to other } \\
\text { internet sources as your MAIN online class reference? }\end{array}$ & 44.3 & 27 & 55.7 & 34 \\
\hline Q5 & $\begin{array}{l}\text { Do you participate in chat sessions after the video } \\
\text { lecture? }\end{array}$ & 96.7 & 59 & 3.3 & 2 \\
\hline Q6 & $\begin{array}{l}\text { Does the discussion session in WA by doing exercises } \\
\text { help you to improve the lesson? }\end{array}$ & 93.4 & 57 & 6.6 & 4 \\
\hline Q7 & $\begin{array}{l}\text { Do the exercises were sufficient to understand the } \\
\text { lesson? }\end{array}$ & 90.2 & 55 & 9.8 & 6 \\
\hline Q8 & $\begin{array}{l}\text { Do you focus better on each discussion in WA } \\
\text { compared to Face-to-Face? }\end{array}$ & 47.5 & 29 & 52.5 & 32 \\
\hline Q9a & $\begin{array}{l}\text { Do you NOT shy to ask questions through WA } \\
\text { discussion? }\end{array}$ & 86.9 & 53 & 13.1 & 8 \\
\hline Q9b & $\begin{array}{l}\text { If yes, does it help you to understand better than face- } \\
\text { to-face? }\end{array}$ & 67.9 & 36 & 32.1 & 17 \\
\hline Q10a & $\begin{array}{l}\text { Does the explanation use the voice message of the } \\
\text { lecturer able to help you to understand the exercises? }\end{array}$ & 95.1 & 58 & 4.9 & 3 \\
\hline Q10b & $\begin{array}{l}\text { If yes, does voice message help you to refresh your } \\
\text { silent learning mood through texting? }\end{array}$ & 93.4 & 57 & 6.6 & 4 \\
\hline Q11 & $\begin{array}{l}\text { Does learning programming use WA make you a self- } \\
\text { learner? (independent learner) }\end{array}$ & 82 & 50 & 18 & 11 \\
\hline
\end{tabular}




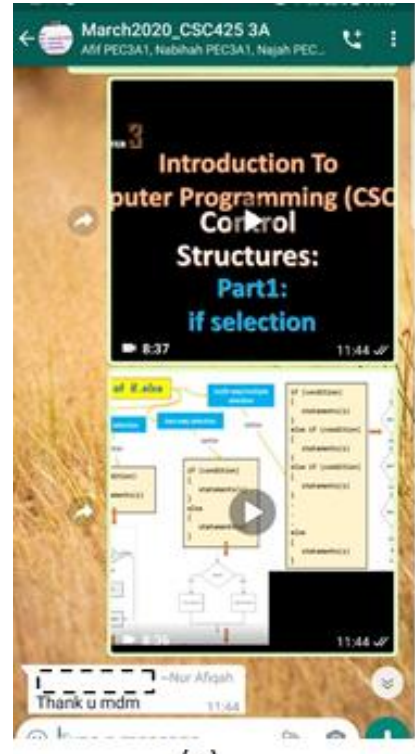

(a)

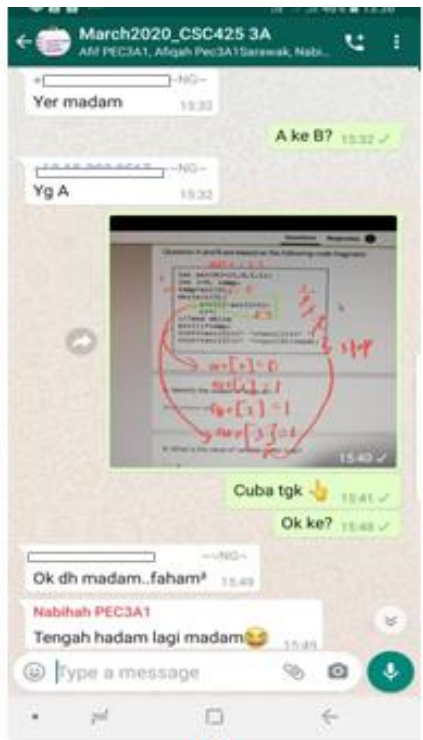

(b)

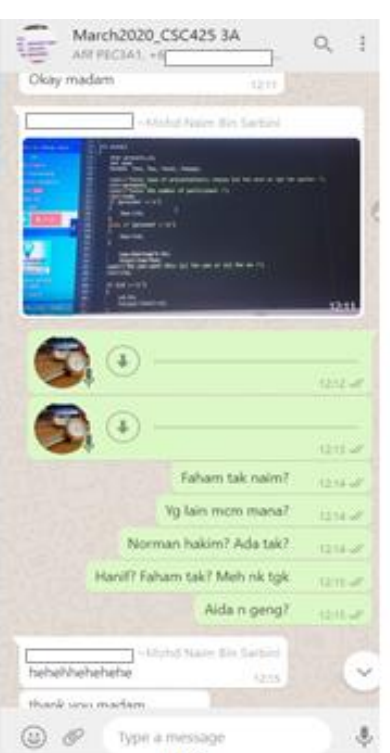

(c)

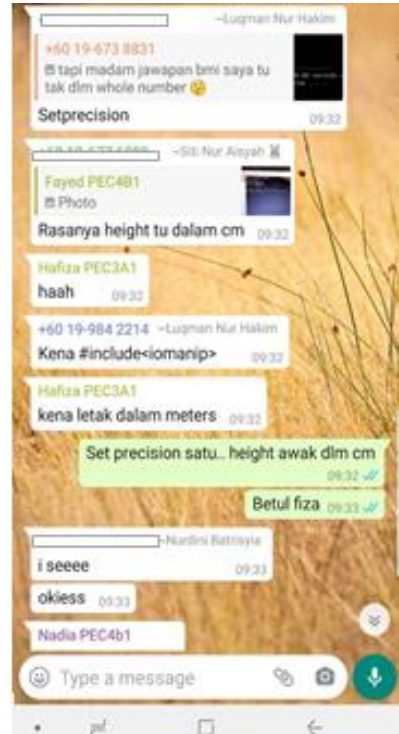

(d)

Figure 2. Screen shoot of utilization of WA features throughout teaching and learning session

Table 2 provides descriptive analysis of attitude of students after learning process through WA application. All respondent has voted to positive attitudes towards learning using WA where the score that agree with $(\mathrm{Q} 12, \mathrm{Q} 13, \mathrm{Q} 14, \mathrm{Q15})$ were more than 50 percent. These results in line with what has reported by Gillingham \& Topper (1999) and Rahaded et al. (2020) that social technology as learning tools improve competency as to learn difficulties in progress of learning with such problem-solving skills, knowledge sharing and discovery.

Table 2. Attitude of Students towards WA learning

\begin{tabular}{|l|l|l|l|l|l|}
\hline \multirow{2}{*}{ Questions } & \multicolumn{3}{l|}{ Agree } & \multicolumn{2}{l|}{ Disagree } \\
\cline { 2 - 6 } & $\begin{array}{l}\text { Q12 } \\
\text { Qhe learning process through WA learning activities } \\
\text { makes learning easy }\end{array}$ & 68.9 & 42 & 31.1 & 19 \\
\hline Q13 & $\begin{array}{l}\text { The learning process through WA learning activities } \\
\text { clarifies the learning sources }\end{array}$ & 88.5 & 54 & 11.5 & 7 \\
\hline Q14 & $\begin{array}{l}\text { The learning process through WA learning activities } \\
\text { favors problem-solving }\end{array}$ & 82 & 50 & 18 & 11 \\
\hline Q15 & $\begin{array}{l}\text { The learning process through WA learning activities } \\
\text { favors faster knowledge sharing }\end{array}$ & 73.8 & 45 & 26.2 & 16 \\
\hline Q16 & $\begin{array}{l}\text { The learning process through WA learning activities } \\
\text { favors the discovery of information useful for learning }\end{array}$ & 86.9 & 53 & 13.1 & 8 \\
\hline
\end{tabular}

Instead of promising benefits of the WA to be applied as e-learning tool, the distance learning is still new but inevitable, yet required students to adapt with the situation. External issues also effect the performance of learning among students. Firstly, the environment at their house which lack of privacy location to do the learning, distraction to do chore during class session and lost of 
internet connection in between class progress due to poor network coverage especially in rural area. Only 15 percent of these students have home internet connection, the rest of them were using mobile connections that easily disrupted when the weather is raining.

\section{Conclusion}

This study was using WA as official medium for lecturer and students to meet and did their teaching and learning. Fruitfully, WA is the best solution tool to study for online distance learning approach when face-to-face approach was disabled. Studying through WA is like you are watching your favorite movie, which full of attention and enjoyable. All of the elements of exciting learning such as interactive, easy for sharing files, fast communication, confidents to ask questions and giving opinions. In this study, students are strongly agreed when lecturer utilizing all of WA features every time of class session. Their continuous and supportive cooperation have demonstrated their confidence in online class. Meanwhile, the positive attitudes flourished when students have better experienced in teaching and learning sessions, this is supported with high scores of questionnaires in Table 1. Confidents in teaching and learning leads them to empower their self-learning techniques, problem-skills, knowledge sharing and discovery in order to score better result. Hence, from this study there is no doubt the potential use of WA or any similar apps used by community to be utilized as distance learning medium.

In future study, extension of teaching and learning will be focusing on the tools suitable to do continuous evaluation of students' assessment. Commonly, assessment is combination of continuous evaluation such as quiz, assignment, test, group project and final examination. The challenge is to evaluate everything online instead of hardcopy.

\section{Corresponding Author}

Syarifah Adilah Mohamed Yusoff

Department of Computer and Mathematical Sciences, Universiti Teknologi MARA (UiTM) Cawangan Pulau Pinang, 13500 Permatang Pauh, Malaysia.

Email: syarifah.adilah@uitm.edu.my

\section{References}

Aina, J. K., \& Ogundele, A. G. (2014). The use of technology for teaching and learning in science and technical education in Colleges of Education, Nigeria. Integrated Journal of British, 1(3), 57-64.

Alfaki, I. M., \& Alharthy, K. (2014). Towards a Digital World: Using Networks to Promote Learners" s Language. American International Journal of Contemporary Research Vol. 4 No, 10.

Amry, A. B. (2014). The impact of WhatApp mobile social learning on the achievement and attitudes of female students compared with face to face learning in the classroom. European Scientific Journal, 10(22), 116-136.

http://eujournal.org/index.php/esj/article/view/3909

Diwan, P. (2017). Is Education 4.0 an imperative for success of $4^{\text {th }}$ Industrial Revolution. Retrieved from https://medium.com/@pdiwan/is-education-4-0-an-imperative-for-success-of-4thindustrial-revolution-50c31451e8a4. 
Gillingham, M. G., \& Topper, A. (1999). Technology in Teacher Preparation: Preparing Teachers for the Future. Journal of Technology and Teacher Education, 7(4), 303-321. Charlottesville, VA: Society for Information Technology \& Teacher Education. Retrieved November 20, 2020 from https://www.learntechlib.org/primary/p/8981/.

Jones, V., Jun, J., \& Philippe, M. (2007). Future School and How Technology can be used to Support Millennial and Generation-Z Students. ICUT 2007(proceeding) $1^{\text {st }}$ Internationa Conference Ubiquitous Information Technology. 12-14.

Laschewski, L. (2011). Innovative e-learning in rural areas: A review. Available at SSRN 1861912.

Mistar, I., \& Embi, M. A. (2016). Students' Perception on the Use of Whatsapp As a Learning Tool in Esl Classroom. Journal of Education and Social Sciences, 4, 96-104. http://jesoc.com/wpcontent/uploads/2016/08/Edu-76.pdf

Pamfilie, R., Bumbac, R., \& Orîndaru, A. (2013). Innovative e-learning benefits for universities and companies. https://doi.org/10.13140/2.1.4383.5527

Pratama, H., \& Kartikawati, S. (2017). The Effect of WhatsApp Messenger As Mobile Learning Integrated with Group Investigation Method of Learning Achievement. International Journal of Science and Applied Science: Conference Series, 2(1), 164. https://doi.org/10.20961/ijsascs.v2i1.16702

Rahaded, U., Puspitasari, E., \& Hidayati, D. (2020). the Impact of Whatsapp Toward Uad Undergraduate Students' Behavior in Learning Process. International Journal of Educational Management and Innovation, 1(1), 55.

https://doi.org/10.12928/ijemi.v1i1.1515

Shariffuddin, S. A., Shaaidi, W. R. W., \& Hashim, S. M. (2017). International Journal of Advanced and Applied Sciences Social networks as instructional tools beyond a classroom. International Journal of Advanced and Applied Sciences, 4(12), 185-192.

Yusoff, S. A. M., \& Kadar, R. (2020). Implementing Google Online and Kami Applications to Supervise Online Distance Teaching and Learning (ODL). Volume 1, September 2020, 76. 